\title{
Surgical treatment of gastric cancer
}

\author{
Smid D, Skalicky T, Dolezal J, Kubackova D, Fichtl J \\ University Hospital in Pilsen, Surgical Clinic, Pilsen, Czech Republic. smidd@fnplzen.cz
}

\begin{abstract}
BACKGROUND: Gastric cancer is a malignant disease which has generally a very bad prognosis. The frequency of occurence of this disease in the population is dependent on the age and localisation. Most frequently, this disease has occured in Japan, China, countries of South Africa and Eastern Europe for a long time but men are more likely to suffer from this disease than women witha ratio of $2: 1$.

METHODS: We retrospectively evaluated the group of patients who had been treated in our complex oncology center in the course of five years

RESULTS: We treated 572 patients with gastric cancer in five years period. 218 patients of the total number were admitted, 185 patients of all hospitalized patients were operated (85\%). 53 patients of our group of hospitalized patients underwent adjuvant oncology therapy (24\%). Overall, five-year survival was $18.4 \%$ in our group, the median survival time was 12.9 months.

CONCLUSION: Radical surgery is considered to be the only treatment modality which can lead to patient's cure under optimal conditions. Complex care for patients with gastric carcinoma should be centralized in big centers. Personalized oncological treatment should be a way how to get better results (Tab. 2, Fig. 5, Ref. 14). Text in PDF www.elis.sk.

KEY WORDS: gastric cancer, total gastrectomy, gastric resection, stent, personalized treatment.
\end{abstract}

\section{Introduction}

Gastric cancer is a malignant disease which has a very bad prognosis in our country. Even if the number of newly diagnosed cases decreases every year, overall mortality from this disease stagnates. Most frequently has this disease occured in Japan, China, countries of South Africa and Eastern Europe for a long time. On the contrary, long-term decrease in gastric cancer is noticed in highly developed countries, such as in the United States of America or Western and Central Europe. However, men are more likely to suffer from this disease than women, with a ratio of $2: 1$. The frequency of occurence of this disease in the population is dependent on age, increasing incidence is directly related to advanced age. Statistical data show that gastric cancer occurs most often in people being in the seventh decennium, on the contrary, this disease rarely occurs in people under 30 years of age. In 2011, the average incidence rate of gastric cancer was 14.7 cases per 100,000 people in the Czech Republic. In the group of people aged between 70 and 80 years, the incidence rate is 68.2 cases per 100,000 . However, from a long-term point of view, most cases are diagnosed at the fourth stage of disease, which significantly influences the survival rate of

University Hospital in Pilsen, Surgical Clinic, Pilsen, Czech Republic, and Charles University, Medical faculty in Pilsen, Surgical Clinic, Pilsen, Czech Republic

Address for correspondence: D. Smid, MD, FN Plzen, Chirurgicka klinika, Alej svobody 80, CZ-323 00 Plzen, Czech Republic.

Phone: +420377104274

Acknowledgements: This work was supported by a grant of the Ministry of Health No. NT14227. patients. The prognosis of patients with gastric cancer is influenced the most by the stage of disease. In case of early stage of gastric cancer, the five-year survival rate of patients is ranges between $60-90 \%$, in comparison with the five-year survival rate of patients in late-stage gastric cancer being determined between 5-20\% $(1,2,3,4,5)$. The necessary condition for successful therapy is radical surgery and the achievement of $\mathrm{R} 0$ resection, the treatment is always palliative without it. Unfortunately, most patients are treated in a palliative way due to late diagnosis.

\section{Materials and methods}

We retrospectively evaluated the group of patients who had been treated in our complex oncology center in the course of five years (from 1st January 2008 to 31st December 2012).

\section{Results}

In the mentioned five-year period, 572 patients with gastric cancer were treated in the complex oncology center of University Hospital of Pilsen. Most patients (62\%) were primarily diagnosed at a different department and were sent to our center to undergo therapy. 218 patients of the total number were admitted to our hospital for gastric cancer and this group of patients was monitored more carefully. Histologically verified gastric cancer was found in 214 patients, GIST was diagnosed in three patients and in one case, histology results were not clear. In the group, there were more patients in the fourth stage of disease (62\%). The distribution of patients in particular stages of the disease is shown in Figure 1. 


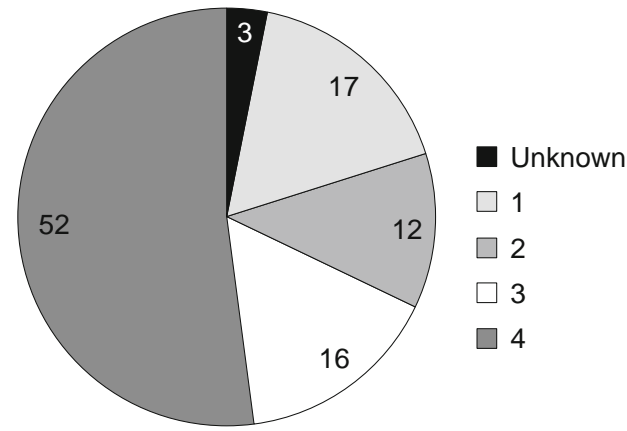

Fig. 1. Distribution of patients according to the clinical stage of the disease.

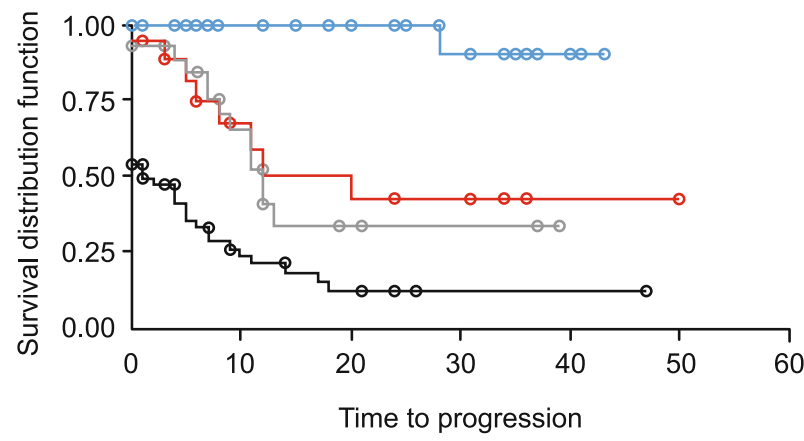

$$
\begin{aligned}
& \text { Loss: } \quad \text { - Stage }=1 \quad \circ \text { Censored stage }=1 \\
& \text { - Stage }=2 \quad \circ \text { Censored stage }=2 \\
& \text { - Stage }=3 \quad \circ \text { Censored stage }=3 \\
& \text { - Stage }=4 \quad \circ \text { Censored stage }=4
\end{aligned}
$$

Fig. 2. Time to progression of the disease according to the stage of the disease.

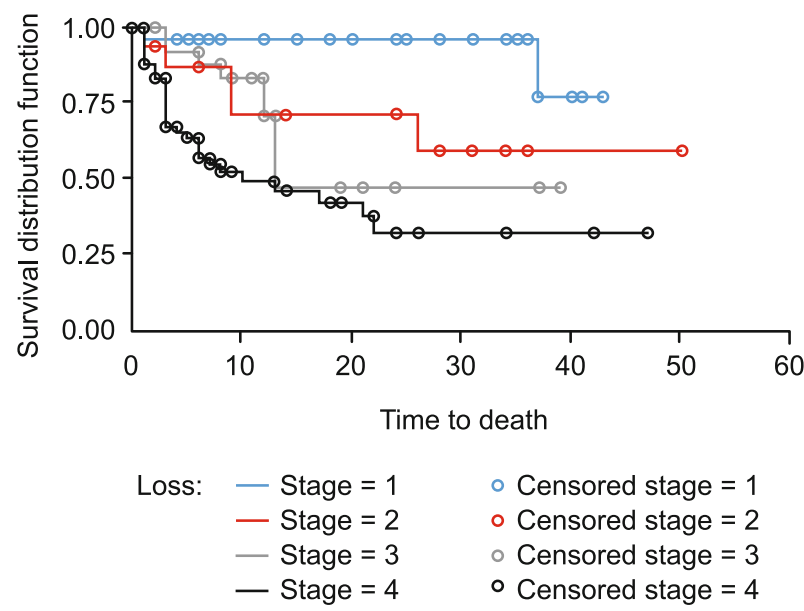

Fig. 3. Overall survival depending on the stage of the disease.

No patient of our group underwent neoadjuvant oncological therapy. 185 patients of all hospitalized ones were operated ( $85 \%)$, subtotal gastrectomy was performed in 64 patients of them (35\%) and 60 patients (32\%) underwent total gastrectomy with following Roux-en-Y digestive tract reconstruction. Block resection was performed in five cases $(3 \%)$. Within all radical performances, we commonly perform lymphadenectomy encompassing the compartment of D1 and D2. Due to the advanced stage of the disease, only exploratory laparotomy was done in 45 patients $(24 \%)$ and in 11 cases $(6 \%)$ gastroenteroanastomosis was performed. We inserted 52 stents in total, which was primary surgery in 32 cases (15\%). In remaining cases, we solved the recurrence of the disease, i.e. rehospitalization. 53 patients out of our group of hospitalized patients underwent subsequent oncological therapy (24\%). Overall fiveyear survival was $18.4 \%$ in our group, the median survival time was 12.9 months. Progression free survival and overall survival depending on the stage of disease can be found in Figures 2 and 3.

Overall survival and time to progression of the disease depending on the type of performance are shown in Figures 4 and 5.

Postoperative complications occured in 32 patients (17\%), there was an accumulation of complications observed in some pa-

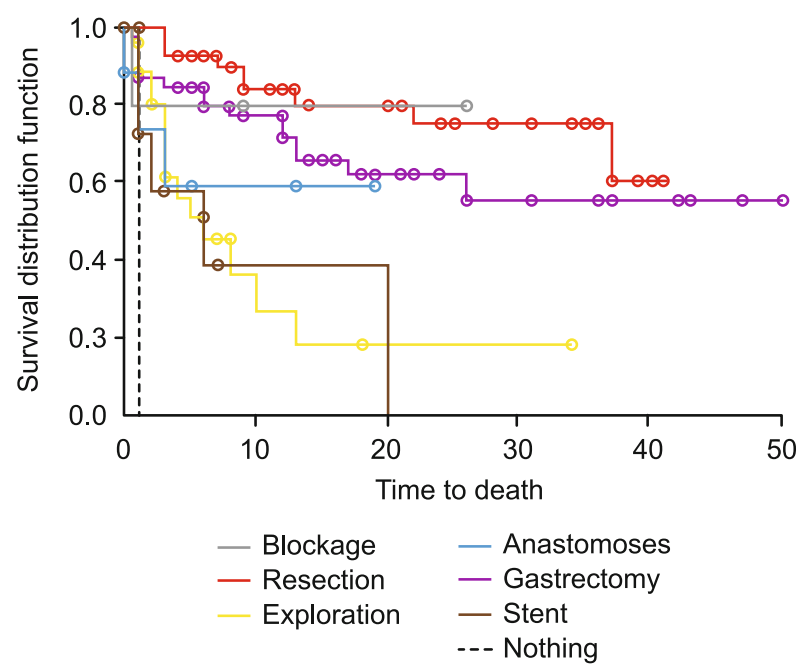

Fig. 4. Overall survival depending on the type of performance.

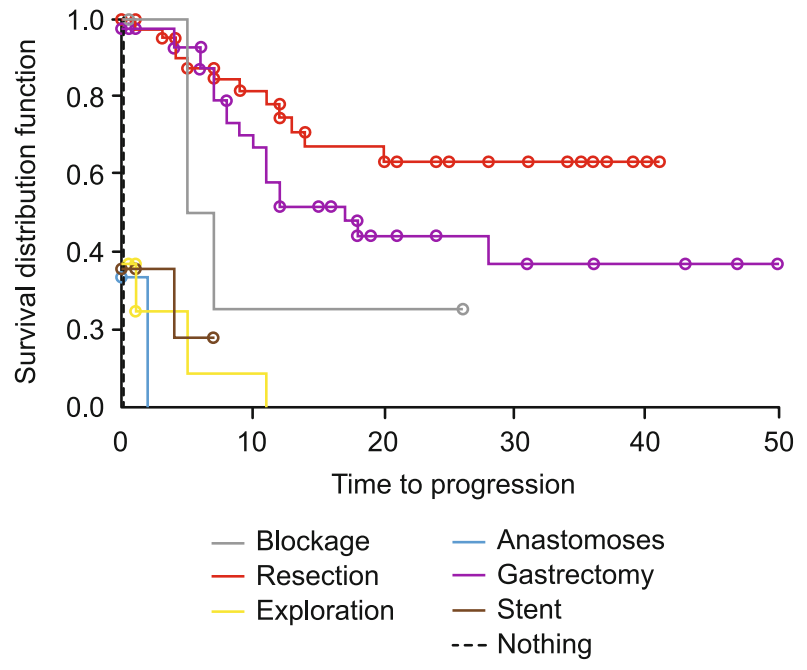

Fig. 5. Time to progression of the disease depending on the type of performance. 
Tab. 1. Postoperative complications.

\begin{tabular}{lc}
\hline Complication & Cases \\
\hline anastomosis leak & 9 \\
intraabdominal absces & 7 \\
laparotomy dehiscence & 1 \\
surgical site infection & 13 \\
acute pancreatitis & 1 \\
bronchopneumonia & 12 \\
cardiac failure & 7 \\
pulmonary embolism & 1 \\
uroinfection & 9 \\
another & 1 \\
\hline
\end{tabular}

tients. 30-day-mortality was $3 \%$ in the group of operated patients. The number of complications is listed in Table 1.

\section{Discussion}

In spite of constantly developing methods for the diagnosis and treatment, gastric cancer is a serious problem which ranks among the most common tumors in humans all over the world. From a global point of view, it is necessary to distinguish countries of the east part of the world from Europe and the U.S.A. Here are some reasons for that. The main one is an efficient and functioning screening programme which is implemented in China and Japan as well as in some parts of Korea. Owing to this, the disease is early diagnosed, which makes results of treatment better. In the U.S.A. and Europe, there has been no screening programme so far and that is why gastric cancer has been diagnosed in an ad- vanced stage of the disease very often for a longer time, which corresponds with its bad prognosis. The repeated studies clearly proved the cost benefit of screening programmes for gastric cancer but despite that these are not globally put into common practice. Another reason is a different body constitution of the population (BMI), which influences the surgeon's possibilities. And last but not least, different charasteristics of the tumor are also discussed. However, this is still a topic of many studies. In spite of the progress and implementation of new oncological preparations, survival rate of patients with gastric cancer has not been improved(4, 5, $6,7,8)$. Therefore, one should take account of the fact that early diagnosis of the disease and radical treatment surgery are decisive factors affecting the patient's prognosis. In case of an endoscopic examination, we use various methods to highlight mucosal changes, which make the diagnosis easier. These are contour reagens - rinse in $1 \%$ acetic acid, chromoendoscopy (dyeing of the gastric mucosa with methylene blue solution, Lugol's solution or Indigo carmine) or Narrow band imaging (special light filtres highlighting the network of capillaries, which makes the detection of small-sized focuses easier). Tissue samples from various pathological focuses are taken for granted, at least three samples are required $(7,8)$. Nowadays, we cannot say any more there is always a need to perform a surgical operation in patients with gastric carcinoma. In cases of an early diagnosis, the method of choice is endoscopic surgery. However, the main condition is the fact that the infiltration does not exceed the muscularis mucosae layer. In accordance with the depth of the invasion, we can select either endoscopic mucosectomy or endoscopic submucosal dis-

Tab. 2. Chemotherapy modes.

\begin{tabular}{|c|c|}
\hline $\begin{array}{l}\text { ECF } \\
\text { Epirubicin } 50 \mathrm{mg} / \mathrm{m}^{2} \text { single dose D1 } \\
\text { Cisplatina } 60 \mathrm{mg} / \mathrm{m}^{2} \text { single dose D1 } \\
\text { 5-Fluorouracil } 200 \mathrm{mg} / \mathrm{m}^{2} \text { daily for } 21 \text { days } \\
\text { repeat from } 22 \text { th day, } 8 \text { cycles }\end{array}$ & $\begin{array}{l}\text { ECX } \\
\text { Epirubicin } 50 \mathrm{mg} / \mathrm{m}^{2} \text { single dose D1 } \\
\text { Cisplatina } 60 \mathrm{mg} / \mathrm{m}^{2} \text { single dose D1 } \\
\text { Capecitabin } 625 / \mathrm{m}^{2} \text { p.o. twice a day for } 21 \text { days }\end{array}$ \\
\hline $\begin{array}{l}\text { FUFA } \\
\text { Leukovorin } 20 \mathrm{mg} / \mathrm{m}^{2} \text { single dose D1-D5 } \\
\text { 5-Fluorouracil } 425 \mathrm{mg} / \mathrm{m}^{2} \text { single dose D1-D5 } \\
\text { repeat from } 29 \text { th day }\end{array}$ & $\begin{array}{l}\text { FAM } \\
\text { 5-Fluorouracil } 600 \mathrm{mg} / \mathrm{m}^{2} \mathrm{D} 1+\mathrm{D} 8 \\
\text { Doxorubicin } 30 \mathrm{mg} / \mathrm{m}^{2} \mathrm{D} 1 \\
\text { Mitomycin C } 10 \mathrm{mg} \text { single dose D1 } \\
\text { repeat from 29th day }\end{array}$ \\
\hline $\begin{array}{l}\text { DCF } \\
\text { Docetaxel } 75 \mathrm{mg} / \mathrm{m}^{2} \text { single dose D1 } \\
\text { Cisplatina } 75 \mathrm{mg} / \mathrm{m}^{2} \text { single dose D1 } \\
\text { 5-Fluorouracil } 300 \mathrm{mg} / \mathrm{m}^{2} \text { daily D1-D14 } \\
\text { repeat from } 22 \text { th day, } 8 \text { cycles }\end{array}$ & $\begin{array}{l}\text { EOX } \\
\text { Epirubicin } 50 \mathrm{mg} / \mathrm{m}^{2} \text { single dose D1 } \\
\text { Oxaliplatina } 130 \mathrm{mg} / \mathrm{m}^{2} \mathrm{D} 1 \\
\text { Capecitabin } 625 \mathrm{mg} / \mathrm{m}^{2} \text { p.o. twice a day D1-D21 } \\
\text { repeat from } 22 \text { th day, } 8 \text { cycles }\end{array}$ \\
\hline $\begin{array}{l}\text { AVA + CPT-11+CisDDP } \\
\text { Avastin } 15 \mathrm{mg} / \mathrm{kg} \mathrm{D} 1 \\
\text { Irinotecan } 65 \mathrm{mg} / \mathrm{m}^{2} \mathrm{D} 1+\mathrm{D} 8 \\
\text { Cisplatina } 30 \mathrm{mg} / \mathrm{m}^{2} \mathrm{D} 1+\mathrm{D} 8 \\
\text { repeat from } 22 \text { th day }\end{array}$ & $\begin{array}{l}\text { ELF } \\
\text { Etoposid } 120 \mathrm{mg} / \mathrm{m}^{2} \mathrm{D} 1-\mathrm{D} 3 \\
\text { Leukovorin } 300 \mathrm{mg} / \mathrm{m}^{2} \mathrm{D} 1-\mathrm{D} 3 \\
\text { 5-Fluorouracil } 500 \mathrm{mg} / \mathrm{m}^{2} \mathrm{D} 1-\mathrm{D} 3 \\
\text { repeat from } 22 \text { th or } 29 \text { th day }\end{array}$ \\
\hline $\begin{array}{l}\text { TCP-B } \\
\text { Avastin } 10 \mathrm{mg} / \mathrm{kg} \mathrm{D} 1 \\
\text { Docetaxel } 30 \mathrm{mg} / \mathrm{m}^{2} \mathrm{D} 1+\mathrm{D} 8 \\
\text { Irinotecan } 50 \mathrm{mg} / \mathrm{m}^{2} \mathrm{D} 1+\mathrm{D} 8 \\
\text { Cisplatina } 25 \mathrm{mg} / \mathrm{m}^{2} \mathrm{D} 1+\mathrm{D} 8 \\
\text { repeat from } 22 \mathrm{th} \text { day }\end{array}$ & \\
\hline
\end{tabular}


section. Sufficient erudition of the performing physician and highquality endoscopic equipment are fundamental prerequisites for the performance of a safe surgery. Nevertheless, we always have to keep the performance of $\mathrm{R} 0$ resection in these cases too to be able to consider the surgery radical and thus curable. Each time it is necessary to examine all resection edges in a pathological way so that the tumor infiltration can be excluded. The resected part always has to be fixed to a cork small plate and properly described so that the pathologist can evaluate the resectional edges of the preparation in an appropriate way. Before determining the indication for endoscopic surgery, we have to know the depth of tumor infiltration of the stomach wall and the histological type of the tumor because endoscopic treatment is not recommended in patients with diffuse gastric cancer. The best pieces of information on tumor infiltration of the stomach wall will be provided by using endoscopic ultrasound. Further, it is necessary to exclude distant metastases which are seldomly noticed in early stages of the disease $(2,8,9,10,11)$. In our country, the diagnosis of early stages of this disease is rare, that is why a minimum number of departments has enough experience with endoscopic treatment. There are more patients with locally advanced carcinoma and distant dissemination of tumor. Due to this fact, radical surgical treatment cannot be performed in most of them. In selected cases, it is possible to indicate the operation connected with palliative resection for a better quality of life. A metallic stent can be inserted in patients with gastric outlet obstruction. Patient's health state is often bad and so palliative chemotherapy cannot be indicated here, either. Such patient's survival is short and the quality of life is poor. The only therapeutic alternative is radical surgery achieving R0 resection. Local operability of tumor and the exclusion of distant generalization including peritoneal dissemination are fundamental prerequisites. Nowadays, there are three types of surgery which are chosen according to the localization of the tumor and its histological type. The indication of total gastrectomy is generally recommended in diffuse tumors, whereas in case of tumors of intestinal type, subtotal gastrectomy can be indicated in accordance with the localization, too. Resection of the distal esophagus and cardia is indicated in patients with gastroesophageal junction tumors. In rare and strictly indicated cases, it is possible to perform multivisceral en block resection aiming at achieving $\mathrm{R} 0$ resection. Current

splenectomy, diaphragm resection, resection of the pancreatic cauda, resection of the left lobe of liver and small bowel resection or large bowel resection are taken into consideration. This surgery is ordinarily indicated in young patients with locally advanced carcinoma without distant dissemination whose health state is good because a risk of possible complications is increasing in relation to the extent of surgery. Lymphadenectomy is quite usually recommended to be performed within D1 and D2 compartments, minimum 15 nodes are suggested to be taken and examined. The contribution of routine lymphadenectomy to D3 compartment is a subject of research, this is not recommended under our circumstances yet for it brings an increased risk of complications and does not make the patient's prognosis better. While indicating the type of surgery, we also take account of the patient's age, the size of tumor, associated comorbidities and general state of health. The way of the subsequent digestive tract reconstruction does not affect the patient's prognosis and is performed in compliance with the surgeon's experience and the custom and habitual practice of the department. Roux-en-Y reconstruction is used in our republic most often. We always have to bear in mind the fact that the contribution of an indicated surgical performance has to be bigger than its risks $(2,6,12,13,14)$. At present, oncological systemic therapy is most grounded on the basis of platin derivatives. There are various schemes of therapy (Tab. 2).

There are various modes of the inclusion of systemic therapy in the whole treatment cycle. Adjuvant therapy is mainly used, although some European studies demonstrated the contribution of neoadjuvant therapy too. An effect of personalized biological targeted therapy is also proved by using bevacizumab or trastuzumab, commonly in combination with conventional chemotherapy. Some studies have proven an effect of the administration of mTOR inhibitor (everolim) and EGFR/HER2 blockade (lapatinib, pertuzumab). The effect of this expensive therapy has to be proved, that is why the effect of systemic oncological therapy is still considered to be supporting and has no decisive influence on the patient's prognosis. In case of gastric carcinoma, radiotherapy has limited significance. Using radiotherapy does not influence survival in a positive way if $\mathrm{R} 0$ resection is not achieved $(2,6)$.

\section{Conclusion}

In spite of improving the diagnositcs as well as therapy possibilities in gastric carcinoma, this is still a serious disease with a bad prognosis. Fortunately, the occurrence of this disease is relatively low in the Czech Republic, in comparison with countries of the Eastern world. So far there has been no screening programme of a high quality which would bring an improvement in diagnostics in early stages of this disease, which appears to be the only possible way how to make therapy results better and to ensure better prognosis. The research of cost benefit ratio of the implementation of the screening programme as well as the implementation of new methods of active searching for patients at risk of gastric carcinoma could be a topic of the next research. Radical surgery is still considered to be the only treatment modality which can lead cure of the patient under optimal conditions. Complex care for patients with gastric carcinoma should be centralized in big centers so that the erudition of the staff could be sufficient and thus top-level care can be provided by up to date medical science could be ensured. The use of specific predictor for therapeutic efect of oncological treatment and use of personalized oncological treatment should be the way how to get better results and long term survival.

\section{References}

1. Becker HD, Hohenberger W, Junginger T, Schlag PM. Chirurgická onkologie. Praha: Grada, 2005

2. Šimša J et al. Karcinom žaludku. Praha: Maxdorf, 2012.

3. Epidemiologie zhoubných nádorů v ČR. www.svod.cz. 


\section{6-670}

4. Kim YG, Kong SH, Oh SY, Lee KG, Suh YS et al. Effect of screening on gastric cancer management: comparative analysis of the result in 2006 and in 2011. J Gastric Cancer 2014; 14 (2): 129-134.

5. Šmíd D, Skalický T, Doležal J, Kubačková D, Fichtl J, Pešta M, Windrichová J, Svoboda T, Kulda V, Daum O. Karcinom žaludku komplexní pohled na nemocného. Practicus 2014; 13 (2): 14-17.

6. Svoboda T, Daum O, Šmíd D. Management léčby karcinomu žaludku. Postgrad Med 2014; 3: 28-31.

7. Pasechnikov V, Chukov S, Fedorov E, Kikuste I, Leja M. Gastric cancer: prevention, screening and early diagnosis. World J Gastroenterol 2014; 20 (38): 13842-13862.

8. Asaka M, Mabe K. Strategies for eliminating death from gastric cancer in Japan. Proc Jpn Acad Ser B Phys Biol Sci 2014; 90 (7): 251-258.

9. Min BH, Kang KJ, Lee JH, Kim ER et al. Endoscopic resection for undifferentiated early gastric cancer: focusin on histologic discrepancies between forceps biopsy-based and endoscopic resection speciment-based diagnosis. Dig Dis Sci 2014; 59 (10): 2536-2543.
10. Gotoda T, Jung HY. Endoscopic resection (endoscopic mucosal resection/endoscopic submucosal dissection) for early gastric cancer. Dig Endosc 2013; 25 (1): 55-63.

11. Jiang N, Liang H, Deng J, Liu H, Cui J, Lian Y, Jiao X. Analysis of clinicopathological characteristics and prognosis of 91 patients with gastric cancer. Asian Pac J Cancer Prev 2014; 15 (19): 8433-8438.

12. Isobe T, Hashimoto K, Kizaki J, Matono S, Murakami N, Kinugasa T, Aoyagi K, Akagi Y. Reconstruction methods and complications in proximal gastrectomy for gastric cancer and a comparison with total gastrectomy neoplasms cancer. Kurume Med J 2014; 20 (30): 10478-10485.

13. NCCN clinical practice guidelines in oncology, gastric cancer, version I.2014, available on www.nccn.org/professionals/physician_gls/pdf/ gastric.pdf.

14. El-Sedfy A, Dixon M, Seevaratnam R, Bocicariu A, Cardoso R, Mahar A, Kiss A, Helyer L, Law C, Coburn NG. Personalized surgery for gastric adenocarcinoma: a metaanalysis of D1 versus D2 lymphadenectomy. Ann Surg Oncol 2014; PMID: 25348779. 